\title{
Remembering Bill Niskanen: pursuing economics as a public science in the service of liberty
}

\author{
Richard E. Wagner
}

Received: 3 January 2012 / Accepted: 4 January 2012 / Published online: 17 January 2012

(C) Springer Science+Business Media, LLC 2012

\begin{abstract}
This short essay is a memorial piece about William A. Niskanen (13 March 193326 October 2011). The essay starts with his time at the University of Chicago in the mid1950s, and gives most attention to his contributions to public choice. Especial attention is paid to his Bureaucracy and Representative Government, which opened vast territory for subsequent analytical exploration. A good deal of attention is also paid to his Autocratic, Democratic, and Optimal Government because this work both conveys his interest in comparative constitutional analysis and is useful for illustrating the strengths and weaknesses of his approach to this material.
\end{abstract}

Keywords William Niskanen · Bureaucracy · Constitutional economics · Welfare economics $\cdot$ Public choice $\cdot$ Economics as public science

William A. (Bill) Niskanen (13 March 1933-26 October 2011) will be well known to readers of Public Choice. His Bureaucracy and Representative Government (Niskanen 1971) was a major contribution in the earliest days of public choice, coming only three years after public choice acquired its name. That book was followed by a lengthy stream of books and papers throughout his life. Bill was also President of the Public Choice Society during 1998-2000. One cannot work in public choice without coming across Bill Niskanen, and repeatedly.

\section{Chicago beginning and foundation}

While Bill did his undergraduate work at Harvard, graduating in 1954, it was at Chicago where he studied until 1957 before moving to RAND that his intellectual orientation took shape. Chicago at this time was strongly personified by Milton Friedman and Arnold Harberger, recognizing that numerous other notable personages were also present. Yet among figures strongly associated with Chicago-style economics during the 1950s, Frank Knight

R.E. Wagner (凶)

Department of Economics, 3G4, George Mason University, Fairfax, VA 22030, USA

e-mail: rwagner@gmu.edu 
had retired in 1955 and George Stigler did not arrive until 1958. Bill's instantiation of Chicago-style economics throughout the corpus of his work can be traced directly to Friedman and Harberger. It was with Harberger that Bill wrote his doctoral dissertation on the demand for alcoholic beverages, having warmed up for the task by writing a Master's thesis on the demand for cigarettes.

Niskanen embraced two traits common to Friedman and Harberger: (1) a belief that the theory of competitive equilibrium provides a good analytical window through which to view the world and (2) good economic models should be simple and parsimonious and yet have rich empirical content. These qualities exemplified Chicago-style economics during Bill's time there and stood in stark contrast to economics as practiced in most other places, where imperfect competition and market failure predominated. The simple and parsimonious character of economic models played out against a background of robustly competitive markets is evidenced crisply in Friedman (1962), which was compiled from class notes several students took during the 1950s. The belief that actual markets are best captured by the theory of competition and not by models of monopoly or imperfect competition is the central theme of Harberger (1954), which argued that the loss from monopoly was only one-tenth of one percent of GDP. While he wasn't at Chicago during Bill's time there, George Stigler (1949) likewise expressed that Chicago theme in debunking monopolistic competition and asserting the superiority of the competitive model. In the same vein, Warren Nutter (1951), another Chicago product, argued that enterprise monopoly was vanishingly small in the United States over the 1899-1939 period. Niskanen's conceptual framework was centered on competitive markets as both useful for its simplicity and as descriptively accurate.

Yet Bill wanted to bring government into this analytical framework, as, of course, did Harberger. The common vehicle for doing this at the time was welfare economics. To this day welfare economics is oriented around the so-called two theorems. The first theorem states that competitive allocations are Pareto efficient. The second theorem states that selections among competitive allocations can be made in non-distortive fashion through lump sum taxes and transfers. The two theorems together have provided a recipe for governmental intervention for most welfare theorists. By claiming that reality is always and invariably imperfectly competitive, market allocations are never Pareto efficient. Hence, there will always exist in principle some intervention that can secure Pareto efficiency even if life is not so simple in practice. Welfare economics was thus mostly viewed as a systematic framework for advocating progressivist principles of state direction of economic activity by articulating the ubiquitous presence of market failure.

In several works, Harberger stood athwart this use of welfare economics, and with this alternative tack summarized in Harberger (1971). There is nothing of which I am aware in Niskanen's body of work that is contrary to Harberger's claim that welfare economics should be based on a postulate of competitive equilibrium. In the hands of market failure theorists, the second theorem provided the vehicle by which those theorists could claim societal improvement for their proposals. These efforts envisioned economic policy as being in the hands of an elite few who could be counted upon to do the right thing as established by their formulations of welfare economics. Niskanen took the nascent public choice theorizing and converted the second theorem from offering normative guidance to some benevolent despot into a positive statement of actual political processes.

As typically presented by people who work with welfare economics, the selection among possible competitive equilibriums is the province of rational thought among economic philosophers regarding principles of justice and equity. Bill recognized the multiplicity of possible societal equilibriums but he most certainly did not regard reasoned and disinterested discussion among philosophical types as the situs where one equilibrium allocation replaces 
another. In this respect Bill was surely closer to Pareto (1935) in regarding such formulations as ideological cover for the realities of the use of power. No one has ever claimed to want to hold political power to do harm; even Adolf Hitler and Joseph Stalin claimed they were seeking to do good work in the world. Vincent Ostrom (1996) notes that the use of power is a Faustian bargain where people use instruments of evil in what they claim is the service of the good. The historical record shows numerous tradeoffs of good and evil, and Niskanen (2003) was one effort to illuminate this tradeoff across regimes.

In contributing mightily to the public choice revolution, Niskanen recognized that the world runs more on intense desires than on pleasant thoughts. Pareto recognized that good ideology could get people to support programs they would oppose if they were to think the matter through. But most people had neither the time nor the inclination to do that. Among other things, there would be no direct return from any such effort. Dispersing the ideological fog spread by political candidates and associated interest groups is a task of great public significance, the performance of which requires some posture of independence and detachment. Bill's early years were perhaps years of warming up for that task, which he subsequently performed with dedication and passion after joining the Cato Institute in 1985.

\section{Liberty and the public significance of economic science}

James Buchanan (1996) explains that economics is a science with considerable public significance because its teachings touch heavily upon the qualities of the structured personal interactions through which societies are constituted. This vision of economics, which has shone through many of Buchanan's writings, and which has been elaborated by Peter Boettke (2011), has been a significant part of Niskanen's professional work. This public quality of economics does not mean that economic scholarship must always be aimed at some general, non-professional audience. It means only that the subject matter with which economics deals touches upon matters that are or should be of interest to people in general. Scholarship reflects a structure of production where, within the division of intellectual labor, some people focus their efforts on deepening the understanding of scholars about their subject matter while other people explain the significance of those formulations to a broader audience. Buchanan, for instance, made little effort at direct public communication throughout his career. In contrast, Niskanen aimed mostly to reach that broader audience though he also developed some significant conceptual formulations.

Bill's career illustrates both his dominant concern with pursuing economics as a public science in the service of liberty and his ability to bridge the two domains of theoretical inquiry and topics of interest to a broader public. He spent only four years in universities, three at Berkeley (1972-1975) and one at UCLA (1980-1981). He left Berkley to join Ford Motor Company, moved to UCLA after leaving Ford, and left UCLA to join President Reagan's Council of Economic Advisers, leaving four years later to join the Cato Institute in 1985, where he stayed the rest of his life. The bulk of Niskanen's life was spent in organizations where his primary activity was to render economic theories intelligible to audiences more interested in implications that could be derived from those theories than in the theories themselves. In this activity Bill was a master, as interested readers can discern by perusing his many works in this genre, a good number of which are available from the Cato Institute, as exemplified by the essays in Niskanen (2008).

To speak of economics as a science with public significance leaves open the kind of economic science that addresses that public significance. Economics is a contested discipline, as Reder (1999) explains. In this vein, postwar economics at Chicago asserted the superiority of the competitive model over claims of imperfect competition, as one illustration of this 
contested quality of economics. Another line of controversy concerns whether economics should posit closed, equilibrated systems as the object of analysis or open and kaleidic systems. In this respect, Wagner (2010) argues that economic theory requires both types of theoretical framework: a closed framework captures social features that are invariant across time and space while an open framework captures the internally generated turbulence that is also a quality of societies.

It has often been noted that eternal vigilance is the price of liberty. Liberty is not the natural condition of humanity. It is rather an artifact that can be secured, if indeed it can ever be said truly to be secured, through the application of eternal vigilance to guard against the collectivisms that appear in many guises. Bill recognized that at base there are only two principles for societal organization: liberalism and collectivism. Either people govern themselves and societies are polycentric arrangements among self-governing entities, or some people are governed by others and societies are characterized in monocentric and hierarchical ways, as illustrated by such status relationships as superior-inferior, dominant-subordinate, or regulator-regulated. Bill was a creative and tireless warrior in the never-ending battle to expand the scope of liberal principles over the continual incursion of collectivist principles that come from many directions, including business corporations, as illustrated by Bill's widely noted dismissal from Ford for failing to advocate protection from foreign competition for Ford.

Economic theory can be pursued from two directions, which Wagner (2010) describes as outside-in and inside-out. Outside-in is the customary direction. It is the direction characterized by the theory of competitive equilibrium that Bill embraced during his student days. It locates the observer outside the object being observed. What is observed is some equilibrium configuration, and existing public policies, along with changes in technologies or preferences, are means of shifting societies to different equilibriums. The inside-out direction of theorizing seeks to locate the theorist inside the object being theorized about. What are observed in this case are not placid equilibriums but processes of continual contestation and turbulence where each observed instant is but a snapshot of a continuing historical process. From the outside-in perspective, property rights might be characterized by the image of lines in the sand which form maps of allowable action open to the various members of a society. The economic theory of free competition examines the features of society in the presence of some such set of lines in the sand. In contrast, from the inside-out perspective those lines are continually being challenged and moved through contests within societies whose qualities are forged and modified through such contestation. In this instance, a particular line stays where it is because those who want to shift it cannot overcome resistance from those who want to keep it where it is, or possibly even move it elsewhere.

Bill's early years were forged dealing with military issues. He worked at RAND during 1957-1962, at the Department of Defense during 1962-1964, and the Institute for Defense Analysis during 1964-1970 before joining the Office of Management and Budget for a twoyear stint. Bill recognized that societies had motion, but true to his Chicago foundation insisted that simple models grounded in competitive equilibrium could allow empirically useful conclusions to be derived. Bill bridged two worlds in helping to supply the eternal vigilance that is a necessary condition for being able to live in liberty.

Niskanen (1971) is the work that Bill is most widely known for among public choice scholars. That book reflected a conceptual architecture that he employed throughout his professional work: simple models grounded on competitive equilibrium under different institutional conditions are used to generate significant empirical implications. In Bureaucracy and Representative Government, Bill treated bureaus as being able to face their legislative sponsors with all-or-nothing offers, thereby transforming consumer surplus into supracompetitive output under the presumption that the desires of bureau officials were promoted 
in direct proportion to the sizes of their budgets. Under certain conditions this generated the striking empirical implication that bureau output would be twice the competitive output. Almost immediately, Bill's formulation came under strenuous criticism, as illustrated by Earl Thompson (1973) and Jean-Luc Migué and Gerard Bélanger (1974), the latter of whom advanced maximizing the discretionary component of a bureau's budget in place of Niskanen's model of maximizing output.

These critics pointed to the implausibility of Bill's presumption that bureau officials had the ability to advance all-or-nothing offers to legislative sponsors. In consequence, the literature shifted to a deeper consideration of knowledge and monitoring in the relation between bureaus and their legislative sponsors. While Niskanen's original framework has been abandoned in light of subsequent examination, his central theme regarding the unique problems regarding knowledge and incentive that pertain to bureaus and their legislative sponsors remains strongly in play in contemporary public choice. Niskanen (1975) is an early reconsideration of his formulation in light of the original criticisms while Niskanen (2001: 258-270) provides a later review of that literature. While Bill's original formulation of output maximization has given way to other models, Bill's original formulation set in motion the scholarly activity that subsequently demolished any rote application of public interest theory to bureau activity, at least without running those theories through ancillary arguments grounded in claims about the knowledge and incentives possessed by the relevant participants.

A recurring theme in Bill's work has been the constitutional arrangements of good government and the many ways in which those arrangements can be eroded. Niskanen (2003) brings Bill's interest in using simple models to generate empirical implications to bear on a comparison of constitutional frameworks. In my judgment, this book illustrates nicely both the virtues and the vices of Bill's approach to his material. The subject he treated there was the economic properties of different constitutional arrangements. This was a work in comparative constitutional systems, approached from within the analytical framework that Bill chose to embrace from his student days: a simple model capable of generating specific implications about the equilibrium properties of different constitutional regimes. He starts by positing three types of constitutional frameworks, which he labels autocratic, democratic, and optimal government. He recognizes that there can be variation among instances of each category, but dismisses such variation as second-order considerations that he didn't want to let obscure his focus on what he regarded as the first-order differences.

To develop specific empirical implications, Bill adapted a new Classical macro framework to his interest in comparative constitutional analysis. True to orthodox macro theory, this framework involved making statements about macro entities without being concerned about how those macro entities might have been generated through interaction among microlevel entities. Bill performed his analysis as an exercise in comparative statics with respect to three different equilibriums. Following standard macro theory, he posited a common CobbDouglas production function where some natural level of aggregate output was modified by taxes and spending, in contrast to macro models where a natural rate of employment is modified by monetary shocks. Within Bill's framework, natural output is independent of regime, which is a necessary presumption for the application of comparative statics across regimes. Similar to real business cycle theorizing, Bill calibrated his model with US data for 1966. Within this aggregative framework, the difference among regimes arose from the different maximization problems which led to different budgetary policies that were applied to the common aggregate production function. Bill defined an autocratic government as one that maximizes the difference between the revenue it extracts from the population and its expenditures on public services; an autocratic regime is treated as maximizing net worth for a 
ruling clique. Facing the same production function, a democratic regime maximizes the net disposable income of the median voter, which in Bill's framework is the person with the median income. In contrast, an optimal government is one that maximizes average disposable income.

What results from Bill's application of this framework has a reasonable quality while also being disturbing in the quiescent posture it portends. With regard to his comparative statics, the democratic regime generates aggregate income that is about $85 \%$ of what an optimal regime would generate. In contrast, an autocratic regime generates only about $55 \%$ of what an optimal regime would generate. These results have plausibility behind them, in that it's easy to point to migration patterns that generally run from autocratic to democratic regimes. It's also easy to recognize that democratic regimes contain room for improvement. What I find disturbing about this formulation is the quiescent or complacent quality that it counsels: democratic regimes always have some room for improvement, but on the whole they are pretty good and, moreover, must always be so because his framework has no room for internally generated metamorphosis.

Yet in earlier work (Niskanen 1977), Bill cited favorably the 18th century Scot historian Alexander Tytler to the effect that democracy was transitory and not permanent due to the clash between the private property necessary for liberty and the collective commons that democracy creates by converting private property into political property. At other places in Niskanen (2003), Bill speaks of constitutional drift and erosion, as well as citing Tytler again and also de Tocqueville on democratic despotism. In doing this, however, Bill is speaking outside the framework of his model, for his model has no space for the transformation from basically liberal to significantly collectivist regimes that has been underway throughout the western world for a century or so.

\section{A personal remembrance in closing}

I never saw Bill Niskanen on a day-to-day basis; we were never colleagues, though once upon a time we could have been. Early in the spring 1966 semester, Bill gave the Friday afternoon seminar in Charlottesville. He presented a model of guerilla warfare. It was one of the most memorable of the seminars I recall from my three years there. It used a simple framework to derive interesting implications. This was job-market season. The next morning Bill interviewed me and offered me a position at the Institute for Defense Analysis. After some reflection, I realized that I wanted to lead the life of a professor more than I wanted the added pay, so declined his offer. Over the years I imagine we were together on average about one occasion per year. Sometimes this would be for a few hours at a seminar or dinner; sometimes it would be for a few days at a conference. There were also such sporadic occasions as spending time in airports or sharing taxis. So this remembrance is written as an outsider and not as an insider: it entails my sense of Bill when seen from a distance and not up close on a continual basis.

If the rules established by the Marquis of Queensbury applied to scholars as they do to boxers, Bill would have been exemplary in his embodiment of those rules. He was a gentleman who was faithful to his calling as a scholar who saw economic science as being in the forefront of the eternal struggle for liberty and liberalism over the persistent forces of collectivism. He would listen politely in all cases, and then tell you his honest reaction in an equally polite manner. He and I didn't always agree, but we always came away with an awareness of the source of our disagreement. And often that disagreement was nothing more than a disagreement about the tasks we were addressing. In my (Wagner 2004) review of 
Niskanen (2003), for instance, I expressed uneasiness with the representative agent quality of his effort to give an aggregate measure of the degree to which actual democracies fall short of what he argued was an optimal outcome. Bill didn't disagree with me, but instead wished me well in coming up with superior formulations. But until I did, he would stick with his parsimonious reductionism based on simple models of competitive equilibrium.

In this posture I have no complaint even though I think many theoretical lacunae remain to be explored in deepening our understanding about internally generated turbulence within human societies. Two people walking north in parallel on a globe will over short periods see no change in the distance between them. Eventually, however, they will realize they are approaching one another. Each of us lives but short periods in the life of the universe, and so might be excused for thinking of social life as occurring on a plane when it really occurs on a sphere. Bill, I know from experience, never objected to efforts to develop alternative forms of explanation, for he had a deep commitment to liberal principles and saw economics as a system of thought capable of bringing support to those principles. Within the public forums within which he operated, however, he recognized a need to advance empirical answers to questions that required closed-form modeling if those questions were to take on life within those forums. There are many paths along which to pursue the public significance of economic science in the service of liberty, but whichever path a scholar might chose he or she will find luminous inspiration in the life and work of Bill Niskanen.

\section{References}

Boettke, P. J. (2011). Teaching economics, appreciating spontaneous order, and economics as a public science. Journal of Economic Behavior and Organization, 80, 265-274.

Buchanan, J. M. (1996). Economics as a public science. In S. G. Medema \& W. J. Samuels (Eds.), How do economists do economics? (pp. 30-36). Cheltenham Glos: Edward Elgar.

Friedman, M. (1962). Price theory: a provisional text. Chicago: Aldine.

Harberger, A. C. (1954). Monopoly and resource allocation. American Economic Review, 44, 77-97.

Harberger, A. C. (1971). Three basic postulates for welfare economics. Journal of Economic Perspectives, 9 , 785-797.

Migué, J.-L., \& Bélanger, G. (1974). Toward a general theory of managerial discretion. Public Choice, 17, $27-43$.

Niskanen, W. A. (1971). Bureaucracy and representative government. Chicago: Aldine.

Niskanen, W. A. (1975). Bureaucrats and politicians. Journal of Law and Economics, 18, 617-643.

Niskanen, W. A. (1977). The prospect for liberal democracy. In J. M. Buchanan \& R. E. Wagner (Eds.), Fiscal responsibility in constitutional democracy (pp. 157-174). Leiden: Nijhoff.

Niskanen, W. A. (2001). Bureaucracy. In W. F. Shughart II \& L. Razzolini (Eds.), The Elgar companion to public choice (pp. 258-270). Cheltenham Glos: Edward Elgar.

Niskanen, W. A. (2003). Autocratic, democratic, and optimal government. Cheltenham Glos: Edward Elgar.

Niskanen, W. A. (2008). Reflections of a political economist: selected articles on government policies and political processes. Washington: Cato Institute.

Nutter, G. W. (1951). The extent of enterprise monopoly in the United States: 1899-1939. Chicago: University of Chicago Press.

Ostrom, V. (1996). Faustian bargains. Constitutional Political Economy, 7, 303-308.

Pareto, V. (1935). The mind and society: a treatise on general sociology. New York: Harcourt Brace.

Reder, M. W. (1999). Economics: the culture of a controversial science. Chicago: University of Chicago Press.

Stigler, G. J. (1949). Five lectures on economic problems. London: Longmans, Green.

Thompson, E. A. (1973). Review of Bureaucracy and representative government, by William A. Niskanen. Journal of Economic Literature, 11, 950-953.

Wagner, R. E. (2004). Review of Autocratic, democratic, and optimal government, by William A. Niskanen. Cato Journal, 24, 181-184.

Wagner, R. E. (2010). Mind, society, and human action: time and knowledge in a theory of social economy. Cheltenham Glos: Edward Elgar. 